\title{
Analysis of the volume of silted sediments and the urbanization rate in urban river basins; a case study of the Mãe d'Água Reservoir
}

\author{
Análise do volume de sedimentos assoreados e da taxa de urbanização em \\ bacias hidrográficas urbanas; estudo de caso Reservatório Mãe d'Água
}

\author{
Felippe Fernandes' \\ Cristiano Poleto"
}

\begin{abstract}
The Mãe d'Água reservoir is the mouth of four streams, corresponding to an area of 352 ha and is located in the Vale Campus of the Federal University of Rio Grande do Sul. The study area is currently predominantly characterized by a residential occupation, with environmental liabilities coming from diffuse sources. The application of the methodology for computational modeling in the Mãe d'Água reservoir, inferring about the useful volume of the project in 1962, useful volume in 2014, and the silting volume was developed with the aid of the following software: AutoCAD 2018, AutoCAD Civil 3D 2018, and Google Earth which specialize in the field of geoprocessing and guidelines for the calculations that use as base the data regarding the survey and processing of field data. Two types of remote sensing products were used to evaluate the evolution of urbanization in the study area: aerial photographs and satellite images which were integrated in a geographic database. Through the results, it was possible to verify that the silting volume occupies approximately $44 \%$ of the useful volume of the reservoir, the urbanization rate has growth trends, and, $88.42 \%$ of the river basin was urbanized in 2014. Thus, it represents a spatial distribution and establishes correlations between sedimentation studies over the last five decades.
\end{abstract}

Keywords: Sedimentation; Rate of urbanization; Geoprocessing; Reservoirs.

\section{Resumo}

A barragem Mãe d’Água é o exutório de quatro arroios, correspondendo a uma área de 352 ha e se situa no Campus do Vale da Universidade Federal do Rio Grande do Sul. No presente momento a área de estudo encontra-se predominantemente caracterizada por uma ocupação residencial, com passivos ambientais advindos de fontes difusas. Aplicação da metodologia para a modelagem computacional no reservatório Mãe D'Água inferindo sobre o volume útil de projeto em 1962, volume útil em 2014 e o volume de assoreamento, foi desenvolvida com o auxílio de softwares: AutoCad 2018, AutoCad Civil 3D 2018 e Google Earth, que são especializados no campo do geoprocessamento e diretrizes para os cálculos que utilizam como base os dados referentes ao levantamento e processamento dos dados de campo. Para a avaliação da evolução da urbanização na área de estudo foram utilizados dois tipos de produtos de sensoriamento remoto: fotografias 'Federal University of Rio Grande do Sul, Porto Alegre, RS, Brazil - fernandes_felippe@hotmail.com.

"Federal University of Rio Grande do Sul, Porto Alegre, RS, Brazil - cristiano.poleto@ufrgs.br. 
aéreas e imagens de satélite, que foram integradas em um banco de dados geográficos. Através dos resultados, foi possível constatar que o volume do assoreamento ocupa aproximadamente $44 \%$ do volume útil do reservatório e a taxa de urbanização com tendências de crescimento e para o ano de 2014 com 88,42 $\%$ da bacia urbanizada, configurando, portanto, uma distribuição espacial e estabelecendo correlações entre os estudos da sedimentação ao longo das últimas cinco décadas.

Palavras-chave: Assoreamento; Taxa de urbanização; Geoprocessamento; Reservatórios.

\section{Introduction}

Anthropogenic modifications in urban areas may imply different environmental liabilities in the hydrological aspect, where water quality, whether superficial or underground, is subject to degradation. When installing / constructing a reservoir in a given water resource, it will have its transversal sections increased, while the flow velocities will reduce, creating the ideal conditions for sediment deposition.

The human action aiming at obtaining the reservoirs with different applicability and functionalities, converts the change of the regime of the environments, transforming the lotic into lentic ones (FERNANDES and POLETO, 2019).

Consequently, the flow of water reaching the reservoir loses kinetic energy and gains potential energy, in a process in which the velocity decreases gradually.

As the velocity decreases, suspended materials that were previously carried by the flow begin to deposit, first the larger and heavier materials, and then the thinnest and lightest materials. These materials deposited in the bottom of the reservoir come from natural and/or anthropic erosive processes, occurring within its contribution river basin (CARVALHO, 2008).

Sediments are a reference to the health condition of an aquatic system, since they act as a reservoir for accumulation of contaminants. The study of the sedimentary columns, "CORES", following the principle of superposition of the geological layers, by which the sedimentary layers are deposited in a sequence of time, with the oldest stratum in the bottom and the newest one in the top, is able to provide the historical record of anthropic activities that have developed in the river basin over the last few years (MÜLLER, GRIMMER and BÖHNKE, 1977, POLETO and FERNANDES, 2018). 
The increase of studies in the scope of hydrosedimentology and the use of geotechnologies appear as a multidisciplinary tool applicable mainly in what concerns spatial and temporal dynamics and environmental management. This provides the necessary support for researches that seek to correlate urban expansion with sediment accumulation near active sources of anthropogenic contamination that can be leached to the water resources present in the river basin.

The present article aims to perform a historical series under the characterization of the sedimentation processes in the Mãe d'Água reservoir and to size silted sediment volumes inside the reservoir and correlate with urbanization rate in the hydrographic basin over the last five decades.

In order to minimize the environmental liabilities generated, it is essential to order urbanization and offer a better infrastructure together with socio-environmental policies and a Degraded Area Recovery Plane (PRAD). Analyzes and the results described in this research aim to offer solutions and methods helping to contain erosion and pollution, sediment transport, sedimentation, and urban drainage in the region.

\section{Material and Methods}

\subsection{Characterization of the Mãe D'Água reservoir}

The site sampled is located in the Rio Grande do Sul State, metropolitan region of Porto Alegre, more precisely in the municipality of Viamão. The Mãe d'Água dam is a tributary of the Arroio Dilúvio, an important water course that goes to the city of Porto Alegre, cutting the eastern direction. The Mãe d'Água dam is in the mouth of 4 streams, corresponding to an area of 353 hectares. It is located in the Vale Campus of the Federal University of Rio Grande do Sul. Figure 1 shows the study area, characterizing the location and the dimension of the dam (FERNANDES AND POLETO, 2017)

Figure 1 - Location and representation of the dam under study in the metropolitan region of Porto Alegre - RS 


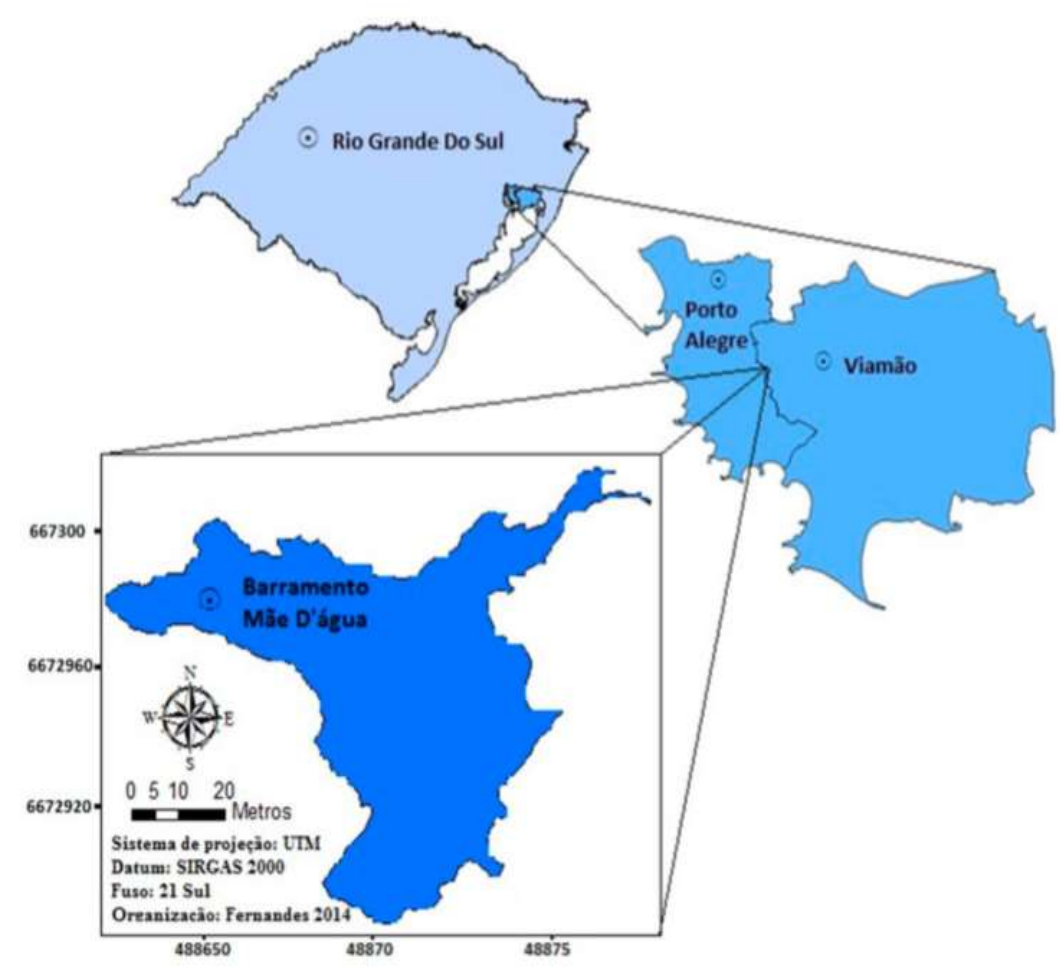

Source: Fernandes and Poleto (2017)

\subsection{Sampling of sedimentary profiles as reference for silted sediment levels in the} reservoir

The points of collection of the profiles were planned, seeking a better spatial distribution in the lake and respecting the local hydrodynamics. A total of eight points were sampled in the reservoir through the CORE's Sampling technique. The local hydrodynamics and the best location and distribution in the lake were analyzed, aiming to obtain the height of the layers of silted sediments at each point, as well as the modeling of the siltation present in the Mãe d'Água reservoir.

The sediment profiles were sampled and their data were tabulated, as well as the geographic coordinates of the points, the water height, and the sedimentary profile length, as shown in Table 1 (FERNANDES AND POLETO, 2017).

Table 1 - Information of the collected sediment cores 


\begin{tabular}{|c|c|c|c|c|}
\hline \multirow{2}{*}{$\begin{array}{c}\text { Sample } \\
\text { (Sedimentary } \\
\text { Profile) }\end{array}$} & \multicolumn{2}{|c|}{$\begin{array}{l}\text { UTM coordinates (m) } \\
\text { (WGS-84 Ellipsoid) }\end{array}$} & \multirow{2}{*}{$\begin{array}{c}\text { Blade } \\
\text { of water } \\
(\mathbf{m})\end{array}$} & \multirow{2}{*}{$\begin{array}{c}\text { Length } \\
\text { of the profile } \\
(\mathrm{m})\end{array}$} \\
\hline & $\mathbf{X}$ & $\mathbf{Y}$ & & \\
\hline$T-1$ & 488716.333 & 6672912.682 & 1.44 & 0.62 \\
\hline$T-2$ & 488730.758 & 6672942.861 & 0.40 & 1.66 \\
\hline T- 3 & 488718.150 & 6672968.704 & 1.24 & 0.82 \\
\hline$T-4$ & 488729.645 & 6672984.722 & 1.48 & 0.58 \\
\hline$T-5$ & 488700.227 & 6672954.527 & 0.72 & 1.34 \\
\hline$T-6$ & 488681.464 & 6672977.900 & 0.44 & 1.62 \\
\hline$T-7$ & 488647.996 & 6672981.868 & 0.48 & 1.58 \\
\hline T- 8 & 488633.545 & 6672976.312 & 1.00 & 1.06 \\
\hline
\end{tabular}

Source: Fernandes and Poleto (2017)

Figure 2 - Spatial distribution of the points sampled in the lake (General view of the points sampled)

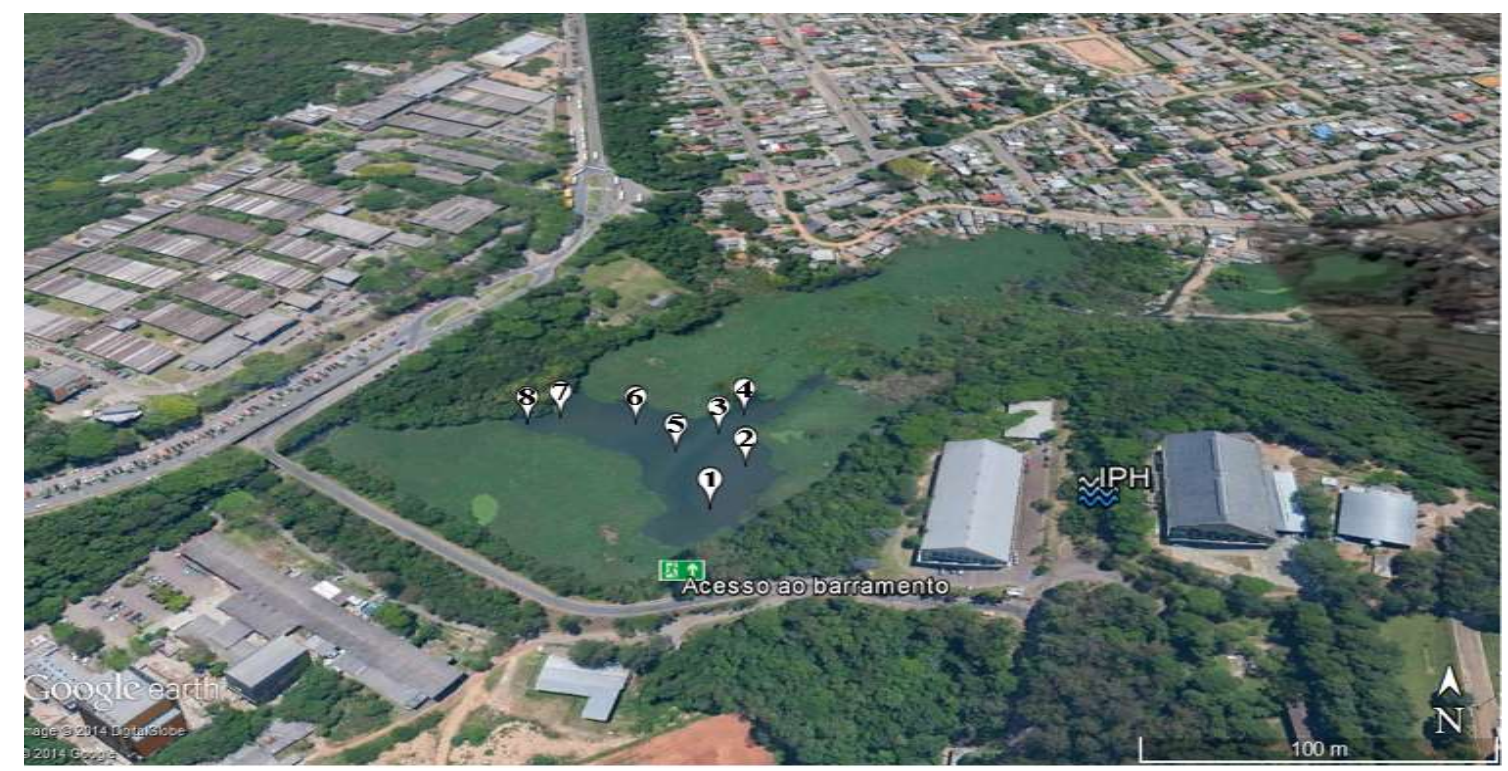

Source: Google Earth (2014)

The technique used was the central sampler (Core Sampling) described by Mozeto (2006) and Fernandes and Poleto (2017). It comprises a set of separate pieces, consisting of the introduction of a cylindrical tube of polyvinyl chloride (PVC) with $75 \mathrm{~mm}$ diameter, (established according to the volume of samples). When the pipe is inserted into the bed of the body of water, a series of impacts on the pipe begins to produce perforation and collection of sediments by a manual force repeatedly, until a sufficiently solid barrier prevents the continuity of the penetration, for the purpose of sample compliance. 
The end of the tube, which had contact with the sediment, has a cutting edge stainless steel which allows the entry of the sediment and has also a retainer to permit the sample to enter and prevent its exit. At the time of collection, a boat was used, which provided safety to the development of the activity, guaranteeing the necessary stability of the crew and the removal of sediment cores (FERNANDES AND POLETO, 2018).

\section{3 Calculation of the reservoir volume and the sedimentation in the reservoir}

For the analysis of the volume calculations, the initial conditions of the reservoir over the year 1962, date of the construction of the reservoir, and later the dimensioning of the volume of silted sediments until 2014 were observed. We first followed the planning and the field outings carried out in 2014, 2015, 2016, and 2017. 4 samplings were collected to achieve the top-bathymetric survey of the reservoir, to collect sediment profiles (help to identify the height of the layers of sediment deposited in the reservoir), and to obtain the data for the said analyzes.

The bathymetric sampling and sediment profiles collected, the collection of bibliographical materials collected in technical researches within the library of the Geosciences and the Institute of Hydraulic Research both located at the Federal University of Rio Grande do Sul provided subsidies for the computational modeling of the reservoir.

The application of the methodology for computational modeling in the Mãe d'Água reservoir inferring about the useful volume of the project in 1962, useful volume in 2014 and the silting volume were developed with the help of the following software: AutoCAD 2018, AutoCAD Civil 3D 2018 and Google Earth, which are specialized in the field of geoprocessing and guidelines for the calculations that use as base the data regarding the survey and processing of field data.

After the compilation of the field data and the bibliographical researches, an analysis was made to establish a retrospective, for years, through aerial photogrammetry, satellite images, and images extracted from Google Earth in order to recover the perimeter of the reservoir in the year of its construction in 1962. The data generated in this step were exported to the AutoCAD Civil 3D 2018 software. 
The use of the software AutoCAD Civil 3D 2018 provided the subsidy to design and calculate the areas and volumes of the reservoir Mãe d'Água using the methodology established by its developers. This is a conical approximation, extracting results on the elevation, area, and volume which are key data to the research. Isobaths or level curves spaced of 0, 08 in 0, 08 meters to calculate the silted volume between 1962 and 2014 were generated.

The calculation method for the conic approach from the AutoCAD Civil 3D 2018 software calculates the volume between two cross sections across the areas, which are added with the square root of their product and multiplied by the third of the distance between the areas to determine the volume, as expressed by Equation 1. As for the total volume, it corresponds to the sum of all partial volumes.

The conic approach method is expressed by the following Equation 1:

$V=\left(\frac{h}{3}\right) \times\left(A_{1}+A_{2}+\sqrt{A_{1} \times A_{2}}\right)$

\subsection{Determination of the urbanization rate of the Mãe d'Água river basin}

To evaluate the evolution of urbanization in the study area, aerial photographs and satellite images of the hydrographic basin and reservoir under study were used and applied in this research in order to obtain the urbanization rates for 1972 and 1991.

With the purpose of assessing the period of urbanization of the area over 2003, an image of the Quickbird satellite was used with spatial resolution of $0.60 \mathrm{~m}$ and made available by Cardoso and Poleto (2013), allowing the monitoring of the evolution of anthropogenic activities that require high precision, such as urban mapping.

For 2008, an image of the Sino-Brazilian satellite CBERS, HRC sensor was used. The delineation of the microbasin was done using the Idrisi Taiga ${ }^{\circledR}$ software from a digital elevation model (DEM) based on the 20 meter isolates of the Brazilian Army map on a scale of 1: 50,000 (Porto Alegre, MI 2987/2).

Finally, to conclude the study of urban development related to the study periods, the year of 2014 and the date of collection of the sediment cores were used. An analysis of the satellite image extracted from Google Earth was utilized. This software is widely used and 
well supported and is applied in environmental studies, which permits to characterize the evolution of the hydrographic basin related to the rate of urbanization of the anthropogenic processes.

On the urban evolution of land use, two classification categories were used: anthropic and natural use. Comparing the years of study with the changes in the hydrographic basin, the anthropogenic effect can be easily observed with regard to urbanization. For example: civil construction, soil waterproofing, reduction of green areas, pasture creation / replacement / increase or grasslands leading to deforestation, among others.

\section{Results and Discussion}

\subsection{Calculation of the useful volume in the Mãe d'Água reservoir}

In order to calculate the useful volume of the Mãe d'Água reservoir, a search was carried out on the characteristics of the project in 1962. This was the date of its construction and the results were achieved through bibliographical references and technical bases from the field sampling in 2014, 2015, and 2016. These two periods were established as a reference for the sizing of the useful volumes and silting.

The volume of sedimentation in reservoirs is an issue that must be addressed because such value will determine the success or useful life of an enterprise.

As a basis for the calculations, the data published by Fujmoto (2002) was followed, such as the adoption of an average depth of 3.15 meters, the top of the dam with a length of 200 meters, and the existence of a layer of clogging.

From the project available for consultation in situ, by the library of the Hydraulic Research Institute of the Federal University of Rio Grande do Sul, data published by the extinct National Department of Sanitation Works (DNOS) was obtained, presenting values referring to the useful volume and elevation of the spillway being $132,462.00 \mathrm{~m}^{3}$ and 104.40 $\mathrm{m}$ respectively.

Figure 3 shows the longitudinal section of the Mãe d'Água reservoir with pertinent data that were used during the calculations. The normal water level and the water level at 
the time of sampling (104.40 and 103.51 meters respectively), the depth of each of the profiles, the maximum limit reached (elevation 101.45 meters), and the rigid colmated sediment layer, belonging to elevation 101.25 meters were all analyzed.

The deepest sampled sediment profile was the T2 with 1.66 meters reaching the elevation of 103.11 meters and the shallowest was the T4 with 0.56 meters with a elevation of 102.01 meters.

Figure 3 - Longitudinal profile of the sediment deposition in the Mãe d'Água reservoir

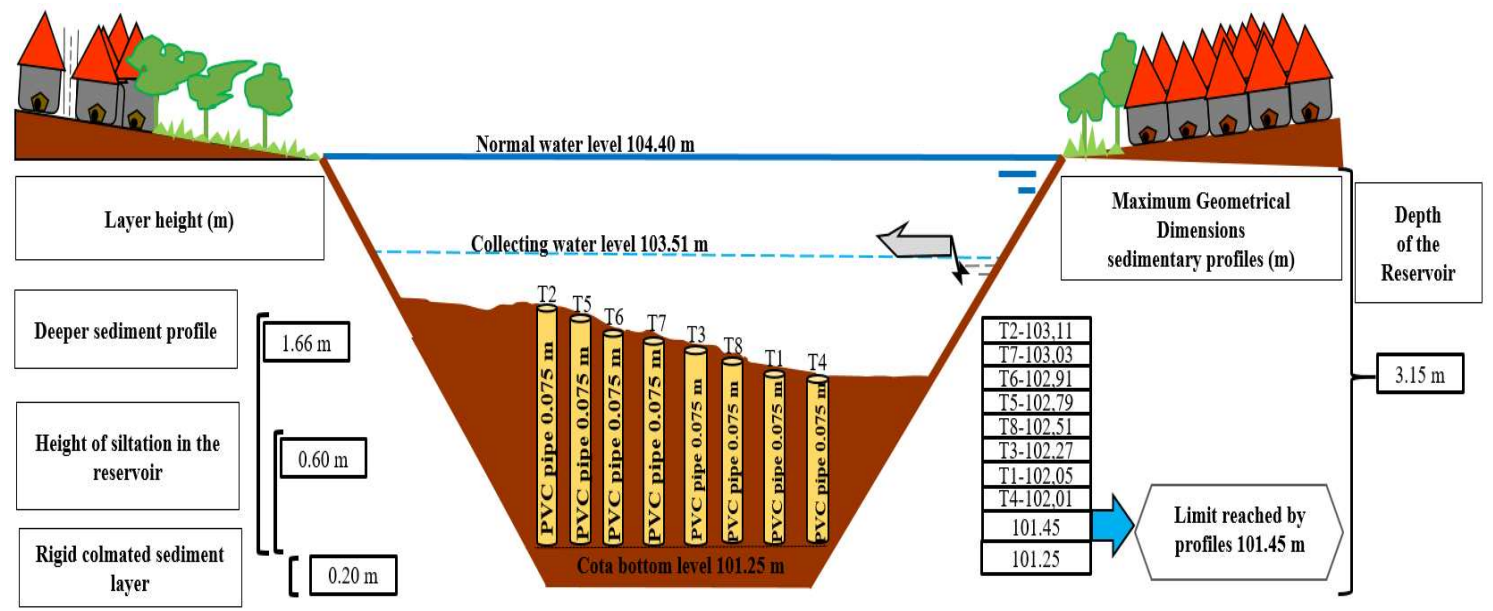

The perimeter of the Mãe d'Água reservoir was measured by the observation of the historical records of the evolution of the water mirror from aerial photogrammetry and satellite images. Thus, it was possible to reconstruct it, taking into account also the crown length, mean depth, and project volume.

This reconstruction was carried out through the AutoCAD 2018 and ArcGIS 10.5 software. Then, the areas of each of the contours were finally determined. Among the advantages of adopting automated approaches to such processes are the reliability and reproducibility of the results, which can then be organized and easily accessed in the form of digital databases (SAUNDERS, 1999).

When applying the conic approach methodology, in order to determine the useful volume of the reservoir, the AutoCAD Civil 3D 2018 software was used. This software uses as a basis for calculations the data from the contours of the isobath or contour areas, the difference between the dimensions, and the perimeter. Table 2 presents data from Elevation versus Area versus Volume for the design of the useful volume of the project in 1962. 
Table 2 - Elevation vs. Area vs. Volume; Method: Conic Approximation

\begin{tabular}{ccccc}
\hline \multicolumn{5}{c}{ Method: Conic Approximation } \\
\hline Elevation $(\mathbf{m})$ & $\begin{array}{c}\text { Layer Height } \\
(\mathbf{m})\end{array}$ & Area $\left.\mathbf{( m}^{\mathbf{2}}\right)$ & Volume $\left.\mathbf{( m}^{\mathbf{3}}\right)$ & $\begin{array}{c}\text { Increment } \\
\text { Volume } \mathbf{( m}^{\mathbf{3}} \mathbf{)}\end{array}$ \\
\hline 101.25 & 0.00 & $38,360.75$ & 0.00 & 0.00 \\
\hline 101.75 & 0.50 & $39,640.99$ & $19,499.56$ & $19,499.56$ \\
\hline 102.25 & 0.50 & $40,760.34$ & $20,099.68$ & $39,599.24$ \\
\hline 102.75 & 0.50 & $41,886.57$ & $20,661.09$ & $60,260.33$ \\
\hline 103.25 & 0.50 & $43,019.66$ & $21,225.93$ & $81,486.26$ \\
\hline 103.75 & 0.50 & $44,159.63$ & $21,794.20$ & $103,280.46$ \\
\hline 104.25 & 0.50 & $45,306.47$ & $22,365.91$ & $125,646.37$ \\
\hline 104.40 & 0.15 & $45,579.41$ & $6,816.43$ & $132,462.80$ \\
\hline Total & & & $132,462.80$ & \\
\hline Average & \multicolumn{5}{c}{$18,923.26$} \\
\hline S. D. ${ }^{*}$ & $42,339.23$ & \\
\hline
\end{tabular}

SD*. - Sample Standard Deviation

After obtaining the values described in Table 2, the correlation analyzes between Elevation versus Area and Elevation versus Volume was established in order to verify the consistency between the two variables, (Figures 4 and 5).

Figure 4 - Elevation versus Mãe d'Água reservoir area relationship by conical approach method

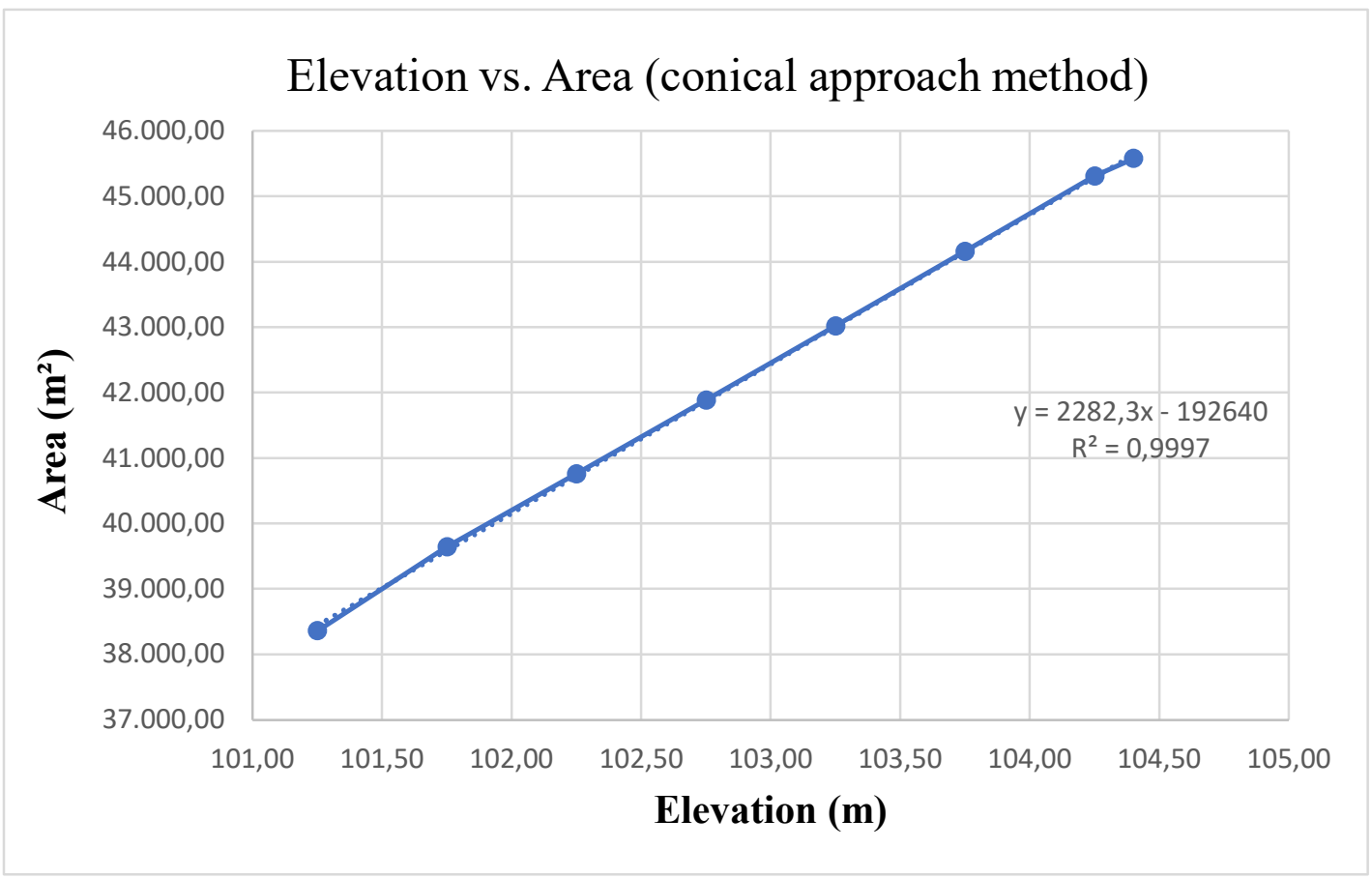


Figure 5 - Elevation versus Mãe d'Água reservoir volume relationship by conical approach method

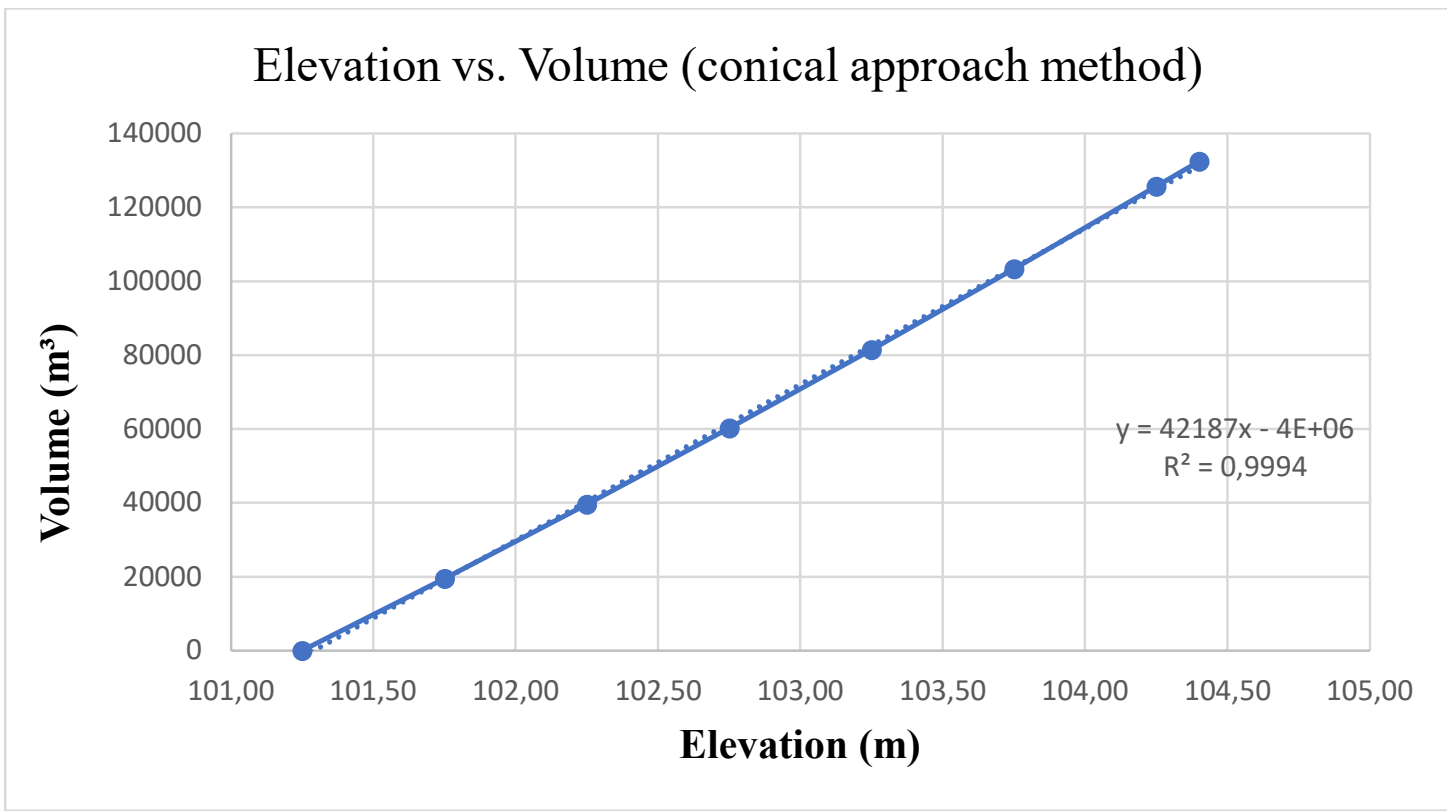

The results for the relationship between the Elevation vs. Area (Figure 4) and for Elevation vs. Volume (Figure 5) both presented good linearity, with correlation between the analyzed data of 0.99 .

The error associated with the volume calculation is low, representing a difference of $0.80 \mathrm{~m}^{3}$ for the project volume in 1962 . Therefore, this method for volume calculation is feasible and reliable for this study.

\subsection{Calculation of the volume of silted sediments}

Initially, an operation was carried out to identify, by means of the digital elevation model, the sedimented regions for each elevation based on the depths of the sediment profiles sampled as these represent the layers of overlapping sediments.

With the aid of AutoCAD Civil 3D 2018 software, the silted sediment volume calculations were performed through the conic approximation methodology.

As input database, this software needs to receive the delimitations of the areas on which one needs to know the relative volumes. In this way, the contour lines were closed in polygonal, with defined areas and dimensions. Finally, the program estimated the volume over the desired area. 
Table 3 presents the data concerning the values of Elevation versus Area versus Volume for the dimensioning of the volume of silted sediments inside the Mãe d'Água reservoir dating from 1962, year of its inauguration, to 2014 which is the year of the samplings, establishing the volume silted in the last decades.

Table 3 - Elevation vs. Area vs. Volume Sediments; Method: Conic Approximation

\begin{tabular}{|c|c|c|c|c|}
\hline \multicolumn{5}{|c|}{ Method: Conic Approximation_(AutoCad Civil 3D 2018) } \\
\hline \multicolumn{5}{|c|}{ Volume of Sediments (silting) } \\
\hline $\begin{array}{l}\text { Elevation } \\
\text { (m) }\end{array}$ & $\begin{array}{c}\text { Layer Height } \\
\text { (m) }\end{array}$ & Area $\left(\mathrm{m}^{2}\right)$ & Volume $\left(\mathrm{m}^{3}\right)$ & $\begin{array}{c}\text { Increment } \\
\text { Volume }\left(\mathrm{m}^{3}\right)\end{array}$ \\
\hline 101.25 & 0.00 & $38,360.75$ & 0.00 & 0.00 \\
\hline 101.75 & 0.50 & $196,644.88$ & $20,318.51$ & $20,318.51$ \\
\hline 102.25 & 0.50 & $201,563.12$ & $14,925.37$ & $35,243.88$ \\
\hline 102.75 & 0.50 & $156,540.28$ & $9,639.00$ & $44,882.88$ \\
\hline 103.25 & 0.50 & $165,376.82$ & $8,109.55$ & $52,992.43$ \\
\hline 103.51 & 0.26 & $59,849.33$ & $4,477.34$ & $57,469.77$ \\
\hline
\end{tabular}

After obtaining the values described in Table 3, Figure 6 was developed. It presents the volumes estimated for the same dimensions in which the contour areas were calculated. Correlations between Elevation versus Area and Elevation versus Volume were done, in order to verify the consistency between the two variables.

According to Macedo (2008), the behavior of the volume area curves for the silted sediment volume calculation presents the same pattern of volume area elevation for the calculation of landfills in the engineering field, since the volume filled by sediments starting from the elevation minimum to the maximum level represents the same volume of landfill between the two elevations. 
Figure 6 - Elevation versus Volume relationship of sediments arranged in the Mãe d'Água reservoir by conical approach method

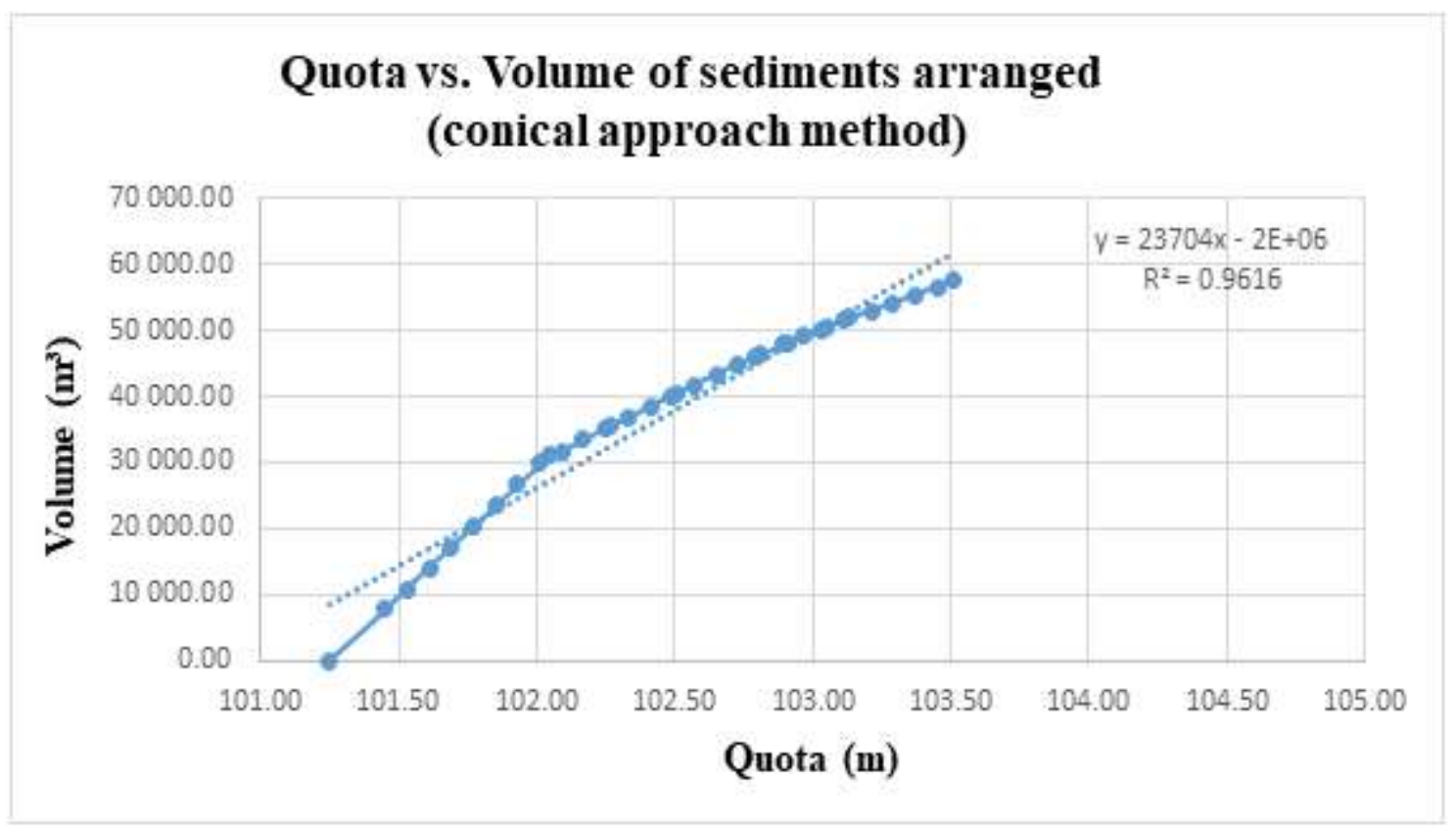

The results for the relations between the two variables presented a good correlation, $(r=0.98)$ indicating that both presented good linearity, with correlation between the data analyzed.

Through the calculation methods presented in this research and the results described in Table 3, we verified that between the years 1962 and 2014, the date of its construction in 1962 and the sampling of the sedimentary records, the total volume of silted sediments inside the Mãe d'Água reservoir was $57,469.77 \mathrm{~m}^{3}$. Such volume represents about $44 \%$ of its useful volume.

According to Araújo (2000), urban reservoirs undergo important environmental changes since their location facilitates anthropic interaction. When calculating the volume of sediments for the Apipucos reservoir, constructed in two cells and located in the urban area of Recife, a mean depth decrease of $15 \%$ was found. Furthermore, an average depth decrease of $11 \%$ occurred in cell 2 . According to the author, these results quantitatively prove that cell 1 of the reservoir is more vulnerable to the ongoing silting process.

Fujimoto (2002) affirms that the process of silting and sealing in the Mãe d'Água reservoir could be surprising, reaching about $50 \%$. In this research, we showed that the value 
described by the author corresponds to the calculated one and that it is necessary the rapid adoption of control measures by the public managers.

The Mãe d'Água reservoir presents sedimentary formation characteristics of the delta type. This is described by Coiado (2001) and Carvalho (2008), occurring inside the reservoir by sediments of various granulometries and has as main consequence the gradual decrease of the volume of the reservoir. These two types of deposits (backwater and delta) can also interfere with navigation by reducing the depth of watercourses.

Figure 7 shows in digital terrain model (3D) the Mãe d'Água reservoir with the characteristics belonging to the year of its construction in 1962. The reservoir had a surface area of approximately $45,574.35 \mathrm{~m}^{2}$ and a useful volume of $132,462.00 \mathrm{~m}^{3}$.

Figure 7 - Digital terrain model (3D) representing the Mãe d'Água reservoir in 1962

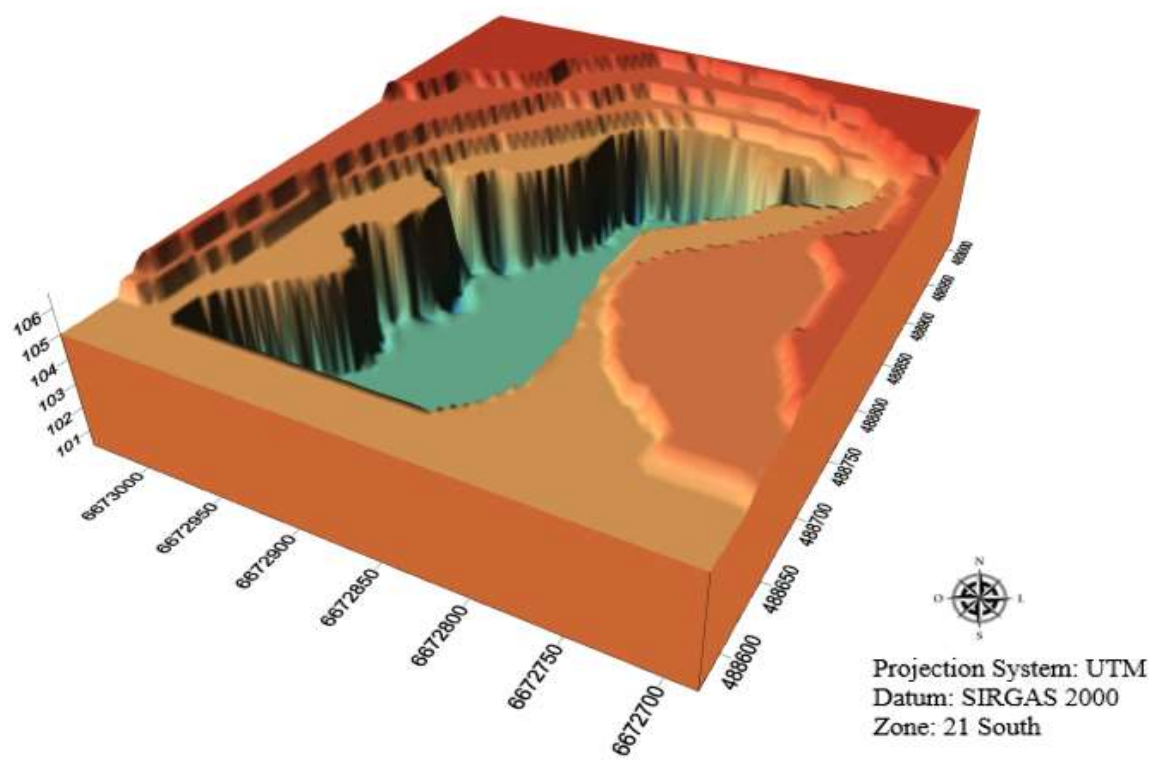

Over the years the river basin was highly urbanized. The municipality of Viamão made feasible the construction of land subdivisions resulting in soil exposure and deforestation beyond the generation of environmental liabilities that would have the reservoir Mãe d'Água reservoir as a final destination.

In view of these anthropogenic actions, Figure 8 characterizes the reservoir with the loss of its useful volume and with its silted bottom. 
Figure 8 - Digital terrain model (3D) representing the Mãe d'Água reservoir in 2014

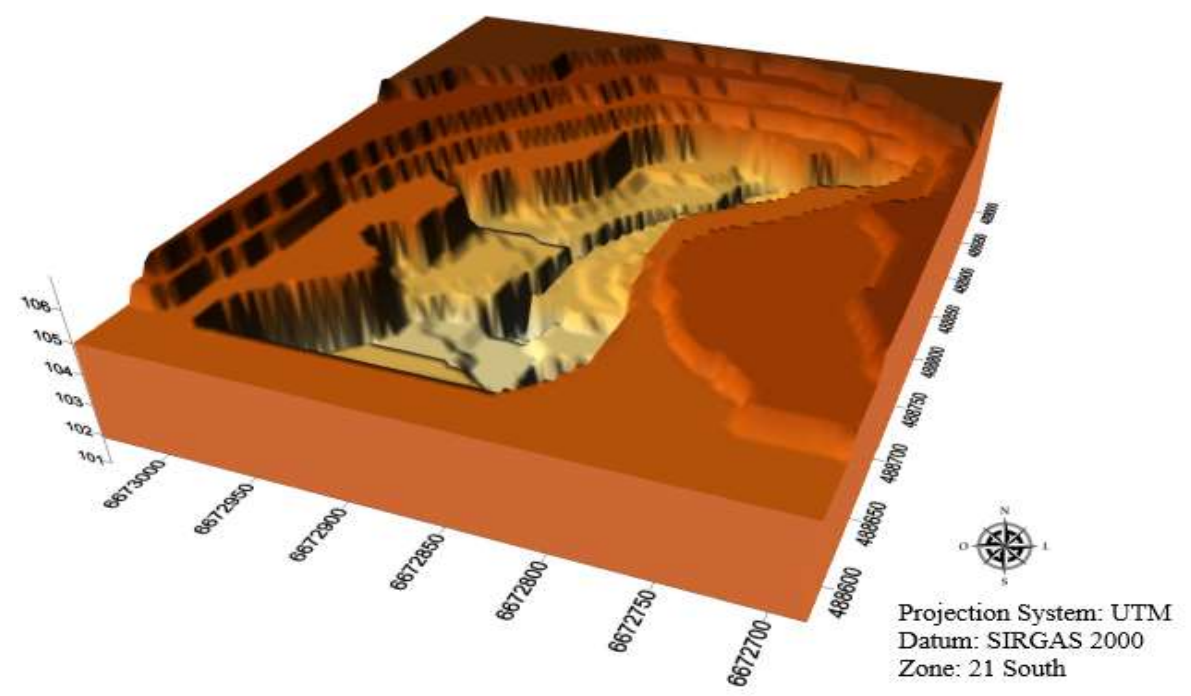

We can verify that the largest deposits of sediment are concentrated in the dam edges in delta formation as described by Morris and Fan (2010). This result is consistent with the expected and with the 3D digital model shown in Figure 8. Larger deposits are formed in the reservoir backwater area, since materials of various granulometries tend to sediment in these regions.

The useful volume in 2014 was determined by the difference between the water volumes in 1962 and the sediments in 2014, calculated from the bathymetric data analyzes that correspond under the influence of the sediment volume deposited and compacted in each reservoir compartment.

The values found were respectively $132,462.00 \mathrm{~m}^{3}$ for the useful project volume and $57,469.77 \mathrm{~m}^{3}$ for siltation. Thus, the volume in 2014 was constituted by $74.992,23 \mathrm{~m}^{3}$ representing approximately $57 \%$ of the total useful volume. Therefore, since its creation until the present date of the collection, the Mãe d'Água reservoir presented a significant loss of its volume and storage capacity.

\subsection{Urbanization rate in the river basin of the Mãe d'Água reservoir}

In order to evaluate the evolution of urbanization in the study area, two types of remote sensing products were used: aerial photographs and satellite images, which were integrated in a geographic database through the ArcGIS 10.5 apps package. 
Two aerial photographs dating from 1972 and 1991, bibliographical surveys on the area, satellite images (QUICKBIRD) and the images of the Sino-Brazilian satellite CBERS data 2008 were used. Finally, satellite images provided by the company Google Earth were also used to represent the years that were detected by the dating of the sediment samples, thus reproducing a good space-time.

The process applied to characterize the use and occupation of the river basin for the year 2014 is presented below through Figure 9. It shows the design of the relative areas with the following data: buildings, paved and unpaved streets and those constituted by parallelepipeds, soil exposed, water resources, tree vegetation, grasses, and pastures totaling the 352 hectares that constitute the Mãe d'Água reservoir.

Figure 9 - Google Earth 2014 image for interpretation of the land use in 2014
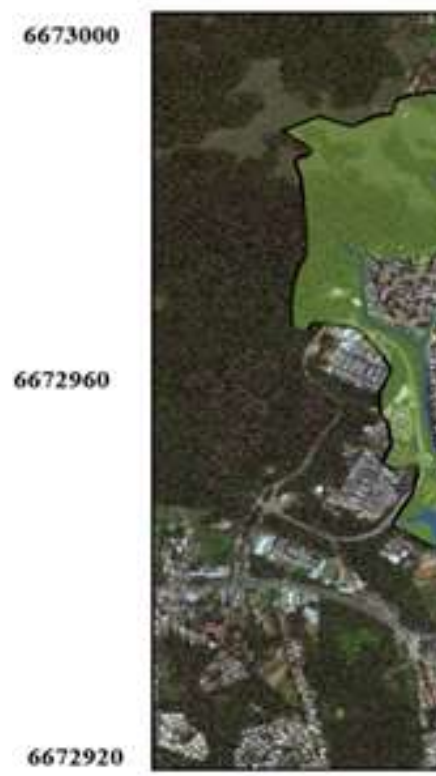

488650

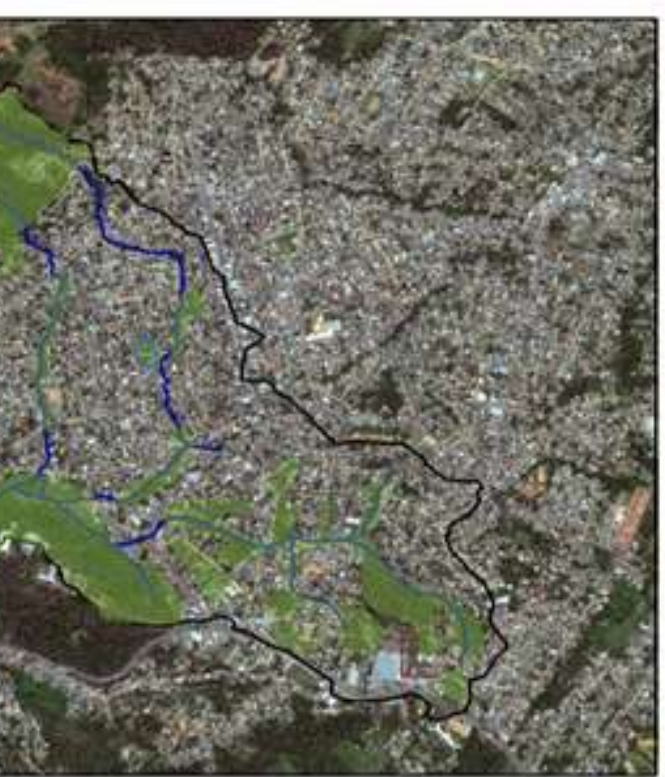

488700

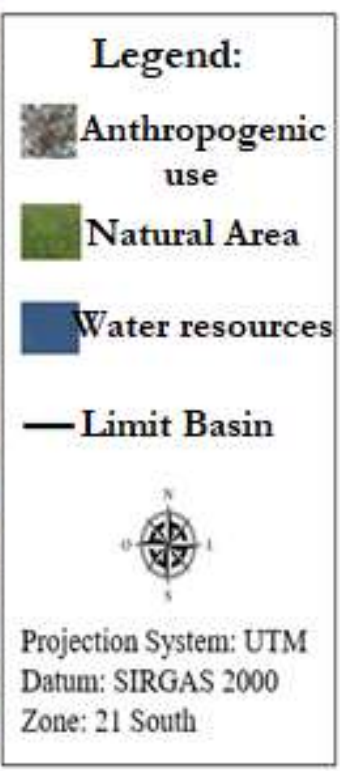

488750

The numbers obtained show variations in the categories evaluated in relation to the data verified in previous years. We observed that the process of urbanization of the river basin is intense, presenting patterns and tendency of growth and evolution of urbanization which reflects negatively on the reservoir, as can be observed in Figure 9.

Figure 10 identifies and expresses the evolution of the urbanization rate in the study watershed from 1972 to 2014 . We can observe the growth of urbanization and the reduction 
of natural areas. It is also possible to notice that the urbanization process is in a growing trend line due to an increase in the use and occupation of the soil in areas where the native vegetation has been removed.

Therefore, there is an increase in urbanization and with the growth of the families living in the area and the lack of locational alternatives for the low-income population have led to the development of small family settlements, characterized by precarious conditions and agglomeration of several dwellings in the same land.

Figure 10 - History of the urbanization of Mãe d'Água reservoir between 1972 and 2014

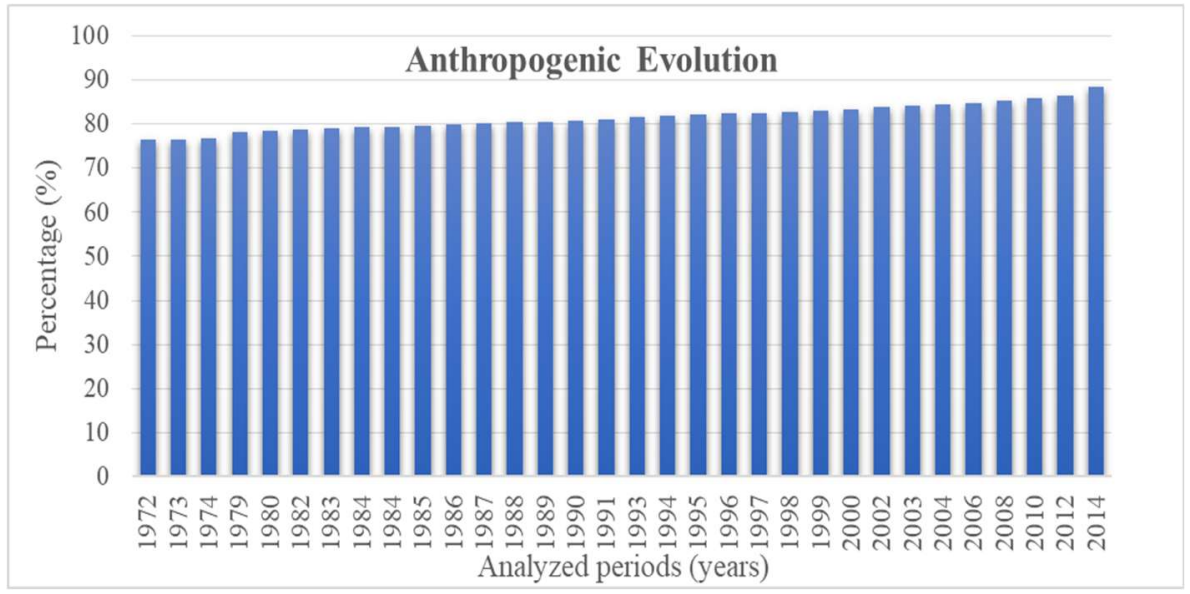

Currently, the area of the river basin of the Mãe d'Água reservoir, object of this study, is predominantly characterized by a residential occupation established throughout its length and perimeter.

The use and occupation of the soil in the basin in front of the scenario and presented conditions propitiates the increase of the generation of the environmental liabilities such as organic and inorganic pollutants, originating from single and / or diffuse sources.

In addition to the contaminants, one must pay attention to the areas with uncovered soil, deforestation, and soil waterproofing, as these cause degenerative effects such as erosion and increased sediment production that through surface runoff, wind action, or landslides, leaches all this material. This results in the silting up of the water resources present in the basin and in the contamination of the ecosystem.

\section{Conclusion}

We observed that the process of urbanization of the hydrographic basin is intense, presenting patterns and tendency of growth and evolution of urbanization which reflects 
negatively in the reservoir. For the improvement of urban management in the planning of anthropogenic activities within the hydrographic basin of interest, it is necessary to use computational technologies that allow the systematization of a large amount of information.

The rapid urbanization in this river basin of the reservoir led to a high production of particulates (sediments) carried by the water resources present in the watershed, causing the silting up of the Mãe d'Água reservoir. It was evidenced by the sedimentation rate over the last 5 decades and by the calculations where it was possible to verify the loss of the useful volume in about $44 \%$ which caused the reduction of the area and the pollution of the reservoir.

Given this complexity of data and information, the Geographic Information System (GIS) and the correlation between the rate of urbanization and the expansion of these environmental liabilities allow this study to be extrapolated to hydrographic basins that have similar characteristics to the study area, (dimensions, land use and occupation, water resources, and urban expansion). As a result, it enables simplified estimates of future risks present in river basins.

This study also is a potential and effective instrument in the elaboration of diagnostics and scenarios on the built environment, which allow, based on spatial analysis, to base proposals for effective interventions for the management of environmental liabilities.

The concern with the water catchment area of the Mãe d'Água reservoir is imminent where urbanization has directly affected the use of the reservoir and, above all, the local ecosystem. The studies described here provide support and a possible update on the city master plan, aiming at better management of water resources and planning and management of the river basin, since its water potential is of the utmost importance for the inhabitants who are extracting and consume this water or even leisure on the spot.

\section{References}

ARAÚJO, A. M. Evolução do processo de assoreamento em reservatório urbano. Anais... IV Encontro Nacional de Engenharia de Sedimentos e I Encontro de Engenharia de Sedimentos do Mercosul, Santa Maria-RS, 2000.

CARDOSO, A. R.; POLETO, C. Evolution of enrichment of sediments by trace metals (Ni and $\mathrm{Zn}$ ) in a dam of urbanized watershed. Lakes reservoirs and ponds, v. 7, n. 1, 2013. 
CARVALHO, N. O. 2008. Hidrossedimentologia prática. Rio de Janeiro: Interciência, $2^{\text {a }}$ Ed. 599p.

COIADO, E. M. Assoreamento de reservatórios. In: PAIVA J. B. D; PAIVA, E. M. C. D (Orgs.). Hidrologia aplicada à gestão de pequenas bacias hidrográficas. Porto Alegre: ABRH, 2001. p. 395-426.

FERNANDES, F.; POLETO, C. Geochemical enrichment of metals in sediments and their relation with the organic carbon. International journal of river basin management, v. 15, n. 1 , p. 69-77, 2017.

FERNANDES, F.; POLETO, C. Geochemistry in Sediment Core for Zinc and Nickel Metals and Comparison between Indexes of Environmental References. Journal of Environmental Engineering, v. 145, n. 3, p. 04018146, 2019.

FUJIMOTO, N. S. V. M. Alterações ambientais urbanas na área da bacia hidrográfica da barragem Mãe D'Água: evolução da ocupação e do uso da Terra. Boletim Gaúcho de Geografia, v. 28, n. 1, 2002.

MACEDO, E. L. Noções de Topografia para Projetos Rodoviarios. 2008.

MORRIS, G. L.; FAN, J. Reservoir sedimentation handbook - design and management of dams, reservoirs, and watersheds for sustainable use. New York: McGraw-Hill Book, 2010. Electronic Version 1.04. 805 p.

MOZETO, A. A. Coleta de sedimentos de ambientes aquáticos continentais, extração de águas intersticiais e determinação granulométrica. In: MOZETO, A. A.; UMBUZEIRO, G. A.; JARDIM, W. F. Métodos de coleta, análises fisico-químicas e ensaios biológicos e ecotoxicológicos de sedimentos de água doce - Projeto Qualised. Cubo Multimidia, São Carlos, 2006. 26p.

MÜLLER, G.; GRIMMER, G. BÖHNKE H. 1977. Sedimentary Record of Heavy Metals and Polycyclic Aromatic Hydrocarbons in Lake Constance. Naturwissenschaften. v. 64, pp.427431.

POLETO, C; FERNANDES, F. Comparative Studies between urbanization and dam settlement processes. European Journal of Sustainable Development. Rome. Vol. 7, n. 3 (oct. 2018), p. 371-380, 2018.

SAUNDERS, W. Preparation of DEMs for use in environmental modeling analysis. In: ESRI User Conference. 1999. p. 24-30. 